\title{
TREES AND BUSINESS DISTRICT PREFERENCES: A CASE STUDY OF ATHENS, GEORGIA, U.S.
}

\author{
By Kathleen L. Wolf
}

\begin{abstract}
As a National Main Street program participant, Athens, Georgia, U.S., has included streetscape tree plantings in economic development efforts. The Main Street program assists downtown merchant groups with physical improvements planning in order to create vital retail environments. If comprehensively managed, the urban forest can be a beneficial long-term improvement. Nonetheless, business people and merchants often have negative perceptions about trees (such as debris and reduced sign visibility) and may influence local policy and budget support for urban forest programs. This study utilized an on-site survey to elicit preference and perceptual response from visitors of the Athens central business district. The presence of a full-canopy forest was found to be associated with higher visual quality ratings of the retail district. District visitors also perceived the streetscape canopy to be an integral amenity of the city's shopping environment. Quantitative and qualitative research outcomes are reported.

Key Words. Urban forestry; retail; business districts; environment and behavior; landscape preference.
\end{abstract}

Athens, Georgia, U.S., home of the University of Georgia, is a distinctive college town, yet its central business district (CBD) has traits that are typical of many mid-sized American cities. Using Athens as a case study, associations between urban forest conditions and consumer preferences and perceptions were studied, to better understand the value of urban nature in creating and maintaining vital business districts. The Athens business community participates in the U.S. National Main Street program. The program's technical assistance enables many cities to implement successful economic development, architectural restoration, and marketing practices. This research may promote better integration of urban forestry with economic revitalization efforts in Main Street program cities.

\section{LITERATURE AND BACKGROUND}

Downtown revitalization programs are often launched due to the exodus of major retailers from the city core to regional shopping malls, or competition from big box discount retailers. Revitalization efforts are intended to create places that have a character or appeal that outweighs the vast product offerings and/or discount pricing of competitive retailers.

The social context of this study exemplifies situations found in many cities. As a long-term participant in the U.S.
National Main Street program, Athens has successfully implemented various district improvements. Ongoing urban forestry activities have been based on implicit, but untested, assumptions that trees contribute to a favorable consumer environment.

\section{Consumers and Nature}

Better understanding of the psychological response of people to both consumer environments and landscapes is central to the success of CBD urban forestry efforts. Human cognitive appraisal of both environments is more complex than mere stimulus response to pleasant appearances.

Shopping and purchasing involve complex cognitive processes. The consumer is aware of some evaluations, while others are nonconscious (Veryzer 1999). Attribution theory describes the inclination of people to subjectively project the traits or satisfactions of a past experience on to a new situation (Weiner 2000). An example is the inferences and impressions of product or store quality that shoppers make upon observing store-based cues (Jacoby and Olson 1987). Visual cues trigger responses to new settings based on both immediate information and recollections.

Store image, or the way in which a store is defined in the shopper's mind, is a cognitive assessment that includes functional qualities and an aura of psychological attitudes (Martineau 1958). Bitner (1992) noted that even before purchase, consumers commonly look for cues about a firm's capabilities and quality. An array of attributes that contribute to store image was identified by Lindquist (1975) and included physical facilities. Store image influences consumers' perceptions of quality of, value of, and willingness to buy products (Dodds et al. 1991).

Psychological response to urban landscapes also includes a complex array of perceptual and cognitive processes (Kaplan and Kaplan 1989). Some investigations have assessed response of people to particular trees in proximity (Sommer 1991; Schroeder and Ruffolo 1996). Others have evaluated the general meaning and values that trees represent for people in urban environments (Chenowith and Gobster 1990; Hull 1992). Natural amenities influence the public's perceptions of urban place and function (Hudspeth 1986; Herzog 1989). 


\section{Research Questions}

Cities contain sizeable areas of retail and commercial land cover. There is extensive evidence of psychosocial benefits from nature in cities (Dwyer et al. 1994; Kuo 2003), but the nature response research has focused on residential and recreational settings and reveals little about urban forest perceptions in retail and commercial districts (Dwyer et al. 1992). In marketing research, the physical setting where product or service and purchaser come into contact has received little attention (Engel et al. 1990), and most studies have addressed indoor environments.

The following research questions guided an investigation of visitor response to the urban forest in outdoor retail environments:

- Does the urban forest influence consumer judgments of visual quality?

- Are there variations in consumer response to streetscape trees, based on consumer traits?

- What are the perceptual responses of district visitors to streetscape trees?

Multiple methods were used, including psychological preference evaluation and contingent behavior scenarios, to ascertain consumer response to streetscapes. Preference and perceptual data are reported here; contingent behavior outcomes are reported elsewhere.

\section{METHODS AND MATERIALS}

Data were obtained in a survey of visitors to the Athens business district in spring 2002. Prior studies of trees and consumer response (Wolf 2003b, 2004) utilized mailed surveys that did not query about local conditions. This onsite survey tested response to a familiar setting.

\section{Case Study Site}

Athens is located $105 \mathrm{~km}$ (65 mi) northeast of Atlanta, Georgia, and is the home of the University of Georgia. Athens is a historic center of commerce and industry for the region, but population migration to suburbs in the 1960s threatened the CBD. Merchants struggled to compete with new strip malls, then regional malls. The Athens Downtown Development Authority (ADDA) was created in 1977 to coordinate $\mathrm{CBD}$ revitalization. Athens became one of several pilot cities of the National Main Street program in 1980.

The Main Street Center, an affiliate of the National Trust for Historic Preservation, advocates urban revitalization using architectural resources and grassroots economic development. The Main Street program provides on-site technical assistance and community training materials. Success stories and techniques are shared via the National Main Street Network, annual conferences, and Main Street Awards program.

Consistent with Main Street program principles, ADDA has encouraged rehabilitation rather than demolition of downtown structures. Outdoor public spaces have been created to complement the historical building stock. ADDA hosts merchant networks and develops comprehensive marketing strategies to attract downtown visitors.

In the late 1970s, an expanding pop music industry fueled the transition of the CBD from a retail center to an entertainment district. Business conversion continued through the 1980s. During the 1990s, the CBD business cohort of nightlife entertainment and specialty retail (e.g., art, jewelry, music) matured.

Trees have been an important part of downtown planning. Large trees are a dominant element of the district's streets, encouraging use of sidewalk cafes and public spaces. A tree program was launched when Athens participated in the federal Model Cities program in the 1960s. Early plantings included Bradford pear (Pyrus calleryana 'Bradford'); ginkgo (Ginkgo biloba), the "city tree"; Darlington oak (Quercus hemisphaerica); honeylocust (Gleditsia triacanthos); and zelkova (Zelkova serrata). Civic groups sponsored additional street tree plantings.

Local government has been committed to tree replacement and maintenance. Of the original plantings, Darlington oaks and ginkgo have done well; Bradford pears and zelkova present maintenance challenges. Infrastructure needs and concerns about maturing trees led to passage of a special tax to fund renovations. Government crews removed declining trees in 2000 and 2001, replacing them with 5 to $6.5 \mathrm{~cm}$ (2 to 3 in.) caliper trees. Citizens objected to the replacements' size, claiming reduced streetscape amenities and business loss. Larger trees have been used in subsequent plantings.

\section{Survey Content}

What are the preferences and perceptions of Athens business patrons regarding trees? A quantitative survey was developed based on prior studies of retail trees (Wolf 2003a, 2004) and landscape assessment (Kaplan and Kaplan 1989). The eightpage, pencil-and-paper instrument included a photopreference section, two sections on retail behavior, and a section of respondent demographics, including respondent age, gender, home community type, household composition, household income, and shopping style.

A photographic image sample was collected in the Athens CBD to represent views typically seen by daytime visitors and shoppers. The color image collection numbered 109; 20 images were used in the survey. Scenes ranged from being devoid of vegetation, to containing mid-size street trees planted at equidistant intervals, to street trees forming a dense, overhead canopy. Image content known to confound viewer response, such as visually prominent people (Herzog 1989) or cloud formations, was avoided. Architectural features are fairly consistent in type and quality. Buildings are one to three stories tall with storefronts adjacent to sidewalks. 
The final page of the questionnaire contained an openended question: "Do you have any thoughts or comments about trees and plants in the Downtown Athens Business District? Please share them here."

\section{Respondent Sampling and Surveying}

Surveys were distributed using on-street, in-person contact. The sampling frame entailed random contact of $\mathrm{CBD}$ visitors by day of week, time of day (between 10:00 A.M. and 8:00 P.M.), and location in the district. Contact sampling was based on pedestrian volume. A total of 24, 2-hour stratified random data collection sessions occurred during a 2-week period, and they were conducted by two-person teams of undergraduate students.

A total of 365 completed surveys were collected. Survey teams intercepted the designated sidewalk users, briefly introducing themselves and the study. Contacts were offered an incentive coupon for a free beverage at a local shop. Following completion (about 10 minutes), respondents were thanked for their participation and given an opportunity to request information about survey outcomes.

\section{Respondent Characteristics}

Respondent traits (Table 1) are consistent with Athens being a university town yet confirm that a diverse sample of district users was achieved. Forty-seven percent of respondents reported that they are University of Georgia students. This demographic is consistent with other variables: age (67\% in their 20 s or younger), time since first visit to district ( $52 \%$ within the past 5 years), community of current residence [55\% in small city (Athens likely)], and annual household income (53\% reporting US $\$ 25,000$ or less).

The cohort of nonstudent respondents, 53\% of users, had attributes of being older, reporting a longer time since their first district visit, having persons under the age of 18 in the household, and having greater household income.

Students are significant contributors to the district economy, yet the ADDA also targets city, county, and state residents for its retail shopping marketing appeals. Response to variables of home ZIP code and size of residence community are indicators of this long-distance visitor pool.

One demographic variable was derived from retail marketing literature-a shopping-style profile (McDonald 1994). Respondents were presented with four brief descriptions and asked to indicate which style best describes their approach to retail, nongrocery shopping. Enthusiasts (those who find shopping enjoyable and make it a social event) made up 28\% of the sample, traditionalists (who are focused and do background research on products) represented $24 \%$, grazers (who enjoy product discovery and impromptu purchases) were the largest group at 32\%, and minimalists (being very directed and task oriented) made up the smallest group at $16 \%$.

\section{ANALYSIS AND RESULTS}

Data analysis involved several approaches. Analytic investigations included response frequencies and distributions, data reduction procedures, and descriptive statistics. Image preferences and open-ended perceptual responses are reported, as well as demographic variations in the responses.

\section{Image Preferences}

Two analysis approaches were used. First, mean image ratings were calculated across all respondents; each was asked to rate how much he or she liked each of 20 images using a Likert scale with 1 denoting "not at all" to 5 indicating "very much" and high preference.

The low- to high-rated images (Figure $1^{*}$ ) display a consistent relationship between the presence of trees in the streetscape and preference ratings, with higher response values associated with increased presence and size of trees. Also, smaller standard deviations associated with higher ratings indicate greater consensus of visitor appreciation for large trees.

The lowest-rated images (having values of 2 or less) contain no vegetation (Figure 2) but only built structures, paving, and cars. Images in the middle range of 3 to 3.6 contain some trees, but built elements dominate the visual array. The highest ratings of 4 or greater depict street scenes containing trees of large size, with canopy that embraces the street and creates outdoor rooms that are of pedestrian scale.

A question tested respondent familiarity, asking, "How many places or locations were you able to recognize?" Seventy-four percent of survey participants claimed to recognize $100 \%$ of the images, $10 \%$ indicated $75 \%$ recognition, and $16 \%$ indicated $50 \%$ recognition or less. Arguably, low image ratings could be attributed to respondents' prior experiences (such as a negative encounter with a merchant), yet the results trend is that positive visual response is associated with degree and character of streetscape greening.

\section{Preferences Categories}

Category identifying methodologies (Kaplan and Kaplan 1989) were then applied to the ratings data, using principal axis factor analysis with Varimax rotation. Dimensions were extracted based on observed covariation of individual items, using interpretive decision rules (Wolf 2004). Three categories emerged, accounting for $45 \%$ of the total variable variance. Seventeen images were included. Categories were labeled after inspection of component images (Figure 3).

Category 1 (Dominant Buildings), having a mean of 1.98, is made up of images that display no trees in the streetscape. Neglected buildings have been found to negatively influence urban preference response (Nasar 1987), but these buildings are well maintained. In addition, the buildings have a historic character, often boosting amenity response to city scenes (Herzog and Gale 1996; Herzog and Shier 2000), 
Table 1. Respondent demographics.

\begin{tabular}{|c|c|c|}
\hline Variable & Responses & $\%$ response \\
\hline \multirow[t]{2}{*}{ Gender } & female & 47 \\
\hline & male & 53 \\
\hline \multirow[t]{4}{*}{ Age } & 20 or younger & 15 \\
\hline & $20 \mathrm{~s}$ & 52 \\
\hline & $30 s$ & 15 \\
\hline & 40 s or older & 18 \\
\hline \multirow[t]{4}{*}{ Time since first visit to district } & up to 2 years ago & 27 \\
\hline & $2-5$ years ago & 25 \\
\hline & $5-10$ years ago & 21 \\
\hline & more than 10 years & 27 \\
\hline \multirow[t]{2}{*}{ U GA student? } & yes & 47 \\
\hline & no & 53 \\
\hline \multirow[t]{5}{*}{ Number of people in household } & 1 person & 15 \\
\hline & 2 persons & 43 \\
\hline & 3 persons & 19 \\
\hline & 4 persons & 17 \\
\hline & 5 or more & 6 \\
\hline \multirow{4}{*}{$\begin{array}{l}\text { Number of people in household } \\
\text { less than } 18 \text { years of age }\end{array}$} & none & 77 \\
\hline & 1 person & 9 \\
\hline & 2 persons & 9 \\
\hline & 3 or more & 5 \\
\hline \multirow[t]{3}{*}{ Home address ZIP code } & Athens/Clarke County & 72 \\
\hline & Georgia & 23 \\
\hline & other locations & 5 \\
\hline \multirow[t]{4}{*}{ Size of community of current residence } & within a large city & 22 \\
\hline & small city & 55 \\
\hline & small town or rural & 14 \\
\hline & college campus & 9 \\
\hline \multirow[t]{5}{*}{ Annual household income before taxes } & less than $\$ 15 \mathrm{~K}$ & 33 \\
\hline & $\$ 15-25 \mathrm{~K}$ & 20 \\
\hline & $\$ 25-50 \mathrm{~K}$ & 16 \\
\hline & $\$ 50-75 \mathrm{~K}$ & 11 \\
\hline & more than $\$ 75 \mathrm{~K}$ & 20 \\
\hline \multirow[t]{2}{*}{ Work in or near district? } & yes & 56 \\
\hline & no & 43 \\
\hline
\end{tabular}

Some totals may not equal 100 due to rounding.

All variables with $93 \%$ or better response rate.

and are the focus of the Main Street program's improvements recommendations. Despite positive building attributes, the streetscapes of this category are judged to have low visual quality.

Category 2 (Buffered Buildings) suggests that trees mitigate visual quality judgments even for austere architecture. These buildings are simplistic in design, lacking the detailing of more historic architecture. They are more massive in form, potentially dominating the street experience. A mean rating of 3.13 is more than a point higher than the category containing images of architecture generally promoted as being more human in scale and having better aesthetic quality.

Category 3 (Green Streets) depicts settings where buildings are observable but trees define the streetscape mood and character. It is difficult to distinguish building detailing or age (though respondents may recall these factors) because tree canopy dominates both the pedestrian environment and the building facades. A common merchant objection to trees is visibility of signs and storefronts (Wolf 2003b). At 4.0, the mean category rating is two points greater than for images having greater business visibility. Streetscape design should simultaneously address trees and signage.

Generally, ratings of visual quality in this study increase with greater tree size and sidewalk enclosure. An additional influence is the ratio of building size to canopy cover, with greater canopy incidence associated with higher amenity judgments.

\section{Demographics and Preference}

Following dimensional analysis, new variables were constructed by aggregating mean values for each variable across all category items for each respondent. The resulting dependent variables were used for independent samples t-test and oneway ANOVA comparisons among respondent groups $(\alpha<0.05)$. Degree of familiarity with the district and proximity of home had no effect on response to the preference categories. Demographic traits demonstrated little influence on ratings, with just a few exceptions. Considering age, people in their 30s rated the least vegetated category lower than people both younger and older $(\mathrm{F}=3.634, \mathrm{df}=2 / 356, \mathrm{p}<.03)$.

Those who work in the district had lower ratings for the Dominant Buildings category $(t=-2.823, d f=355, p<.005)$, suggesting that green streets may contribute to employee satisfaction. Those claiming a minimalist shopping style rated the Green Streets category lower than other shoppers $(\mathrm{F}=5.692, \mathrm{df}=3 / 348, \mathrm{p}<.001)$, a finding consistent with the utilitarian, nonamenity interests of these shoppers. 
Remarkably few traits distinguish district visitors' visual response to trees in the Athens streetscape. A full canopy cover that defines the character of the pedestrian space is highly appreciated by all district visitors, as demonstrated by both preference ratings and subsequent category analysis of the image set.

\section{Perceptual Responses}

In response to the concluding open-ended question, 186 respondents (51\%) wrote comments. In a mixed methods approach, analysis of direct responses discloses human values, adding dimension to numerical expressions.

Techniques and conventions of quantitative data analysis are well established; qualitative analysis has fewer generally acknowledged procedures. Yet there are approaches that, like quantitative analysis, seek to systematically generate outcome themes and reduce data volume to key understandings. Using a simplified content analysis procedure (Robson 2002, Creswell 2003), each individual comment was coded using a theme template derived from inferential inspection of the entire set. Effort was made to generate interpretive themes that were exhaustive and mutually exclusive. Item coding was done during multiple readings of the data set, and response themes were further refined.

Five response themes are listed in Table 2 based on item counts: Tree Benefits (92), Tree Quantity (66), Removal and Preservation (49), Design and Detailing (47), and Miscellaneous (31). Some responses spanned more than one theme; thus, the item sum is greater than respondent count.

Tree Benefits contains three subthemes. First, downtown Athens trees were recognized for their contributions of environmental benefits. Second, respondents noted how trees contributed to the amenity value (comfort and beauty) of the business district. The third benefits topic is most salient-the role of trees in attitudes about the Athens CBD. District perceptions describe how the urban forest contributes to a sense of place, and the consequences of the loss of large trees.

The urban forest is often taken for granted until an incident galvanizes citizen attention. Examples are storm events or insect infestations that cause high tree mortality. One respondent found that simply completing the survey raised awareness of the value of trees:

I am a born and bred Athenian, and have never taken a specific interest in the layout of downtown. However, as I was checking off the pictures, I realized the difference in how I rated the photos with trees and without. I think downtown Athens would be extremely more vibrant with the addition of more greenery.

The second response theme, Tree Quantity, contains requests for more trees, connecting tree count to district character. The third, Removal and Preservation, contains attitudes about recent changes in the CBD urban forest due to infrastructure construction. Many respondents lamented
Table 2. Open response themes and key phrases.

Theme: Tree Benefits (92 responses)

Subtheme: Environmental Benefits

Downtown wildlife habitat

Reduce heat radiation

Air purification

Shield people from the rain

Buffer noise

Buffer auto pollution

Subtheme: Amenity Value

Are beauty of the town

Are aesthetically pleasing

Shade the sidewalks

Provide us with pleasure for years to come

Soften the look of the storefronts

Make the city a better place to live and visit

Add color to the store-fronts

Make being downtown pleasant

Subtheme: CBD Character

Make downtown more inviting

Important part of the downtown atmosphere

Create pedestrian pockets for people

Make area less stark

Are good for keeping me downtown

Make Athens the place that it is

Distinction and personality

Without trees would be a cement garden

\section{Theme: Tree Quantity (66 responses)}

Plant more in the district

More trees are ALWAYS a good idea

Plant as many as you can-quick!

There couldn't be too many

More dogwoods

More trees and greenery-more social activities

Theme: Removal and Preservation (49 responses)

Replacement-I was upset

Don't uproot healthy trees and replace with smaller ones

Destruction of trees detrimental to downtown

Travesty to remove any of the large shade trees

\section{Theme: Design and Detailing (47 responses)}

Do not like the new brick/gravel sidewalks

Red brick is nice

Important to have sidewalk planters

Consult "New Urbanism" and sustainable community design

Prefer bigger, fuller trees—not the little ones

\section{Theme: Miscellaneous and Non-Trees (31 responses) \\ Dissatisfaction with constant construction \\ Parking issues should be addressed \\ Morning trash around bars}


the loss of large trees. While few citizens may understand the complexities of gray infrastructure installation, the comments reinforce the need for adequate planning for trees during construction work.

Design and Detailing, the fourth theme, suggests that district users are sensitive to the finer details of the streetscape design and materials used for recent sidewalk work. The small size of replacement trees was particularly noted. Comments about the ubiquitous issues of business districts, such as parking and trash management, made up the final theme.

\section{DISCUSSION}

A tree replacement program in Athens, Georgia, prompted public debate about the urban forest in the city's retail core. This study, including both preference and qualitative responses, empirically assessed users' appreciations for streetscape trees.

Preference analysis results are consistent with other retail district studies (Wolf 2003b, 2004). Large trees and full canopy are most preferred. Modern architecture that is visually buffered by trees is more preferred than historic architecture having no trees. Clean, well-kept buildings are essential for creating a welcoming consumer environment, yet the balance of building age and nature amenity is important.

Plants affect consumers' judgments of visual appeal, as demonstrated by a two-point difference in the category mean ratings. The most preferred scenes depart from metatrends of prior studies (Kaplan and Kaplan 1989). Generally, scene ratings above 3.0 for images depicting human influence have been bestowed on scenes containing a cultural element that does not dominate natural content, say a boardwalk or a small building in a park. Five highly rated scenes in this study depict buildings at urban densities. Visual quality in urban settings can be enhanced with careful blending of hardscape and nature.

The trees and preference effect was influenced little by respondents' personal traits, familiarity with the district, or shopping style. Judgments of visual quality are directly associated with trees, and are shared by all Athens CBD visitors.

\section{Consumer Cognitions}

Preference results tell us more than simply what is "pretty" in the shopping environment. Physical cues generate cognitive interpretations of store image and quality. Marketing research about "atmospherics" indicates that subtle physical conditions are correlated with behavioral response. Interior store features, such as soft lighting, classical music, and open layout are associated with high image stores, whereas bright and harsh lighting and grid layout are associated with low-image stores (Grewal and Baker 1994). Pleasant store settings are significant predictors of willingness to spend time in a store and of intentions to spend more money than originally planned (Donovan et al. 1994). Furthermore, store image influences consumers' perceptions of quality and value and of their willingness to buy products (Dodds et al. 1991).

Atmospherics studies have focused on store interiors; analogous cognitions probably occur in the streetscape setting. Visitor response in Athens is consistent with preference evaluations of other landscapes. The presence of trees enhances public judgment of visual quality in many outdoor environments (Kaplan 1985; Ulrich 1986; Smardon 1988). People also respond to scenes based on the balance between human influence and natural content, with more nature in a scene evoking higher landscape preference (Kaplan and Kaplan 1989). Studies on nature and city streets find that both evaluative appraisals (Nasar 1987) and affective response (Sheets and Manzer 1991) are boosted by the presence of trees.

The urban forest may be the streetscape equivalent of interior store atmospherics. Does consumer behavior correlate with judged visual quality? If consumers do not find the street environment appealing, or infer negative traits from the streetscape, they may not spend time in the stores that compose the district. This inference is supported by the respondents' qualitative responses.

The ongoing success and vitality of local business districts is a practical issue of great concern. The Main Street program offers a comprehensive approach to placebuilding and place-marketing for retail revitalization. Few studies have empirically assessed the economic benefits of the entire palette of Main Street improvements (Smith 2001), nor the specific values of having a quality urban forest in a CBD. This study confirmed that the well-planned, canopy-covered streets of Athens, Georgia, are highly appreciated by visitors. Other business improvements programs should tap the psychological appeal of trees to attract consumers.

\section{LITERATURE CITED}

Bitner, M.J. 1992. Servicescapes: The impact of physical surroundings on customers and employees. J. Market. 56:57-71.

Chenowith, R.E., and P.H. Gobster. 1990. The nature and ecology of aesthetic experiences in the landscape. Landscape J. 9(1):1-8.

Creswell, J.W. 2003. Research Design: Qualitative, Quantitative and Mixed Methods Approaches. Sage, Thousand Oaks, CA.

Dodds, W.B., K.B. Monroe, and D. Grewal. 1991. The effects of price, brand and store information on buyer's product evaluations. J. Market. Res. 28:307-319.

Donovan, R.J., J.R. Rossiter, G. Marcoolyn, and A. Nesdale. 1994. Store atmosphere and purchasing behavior. J. Retail. 70(3):283-294. 
Dwyer, J.F., E.G. McPherson, H.W. Schroeder, and R.A. Rowntree. 1992. Assessing the benefits and costs of the urban forest. J. Arboric. 18(5):227-234.

Dwyer, J.F., H.W. Schroeder, and P.H. Gobster. 1994. The deep significance of urban trees and forests, pp 137150. In Platt, R.H., R.A. Rowntree, and P.C. Muick (Eds.), The Ecological City: Preserving and Restoring Urban Biodiversity. University of Massachusetts Press, Amherst, MA.

Engel, J.F., R.D. Blackwell, and P.W. Miniard. 1990. Consumer Behavior. Dryden Press, Chicago, IL.

Grewal, D., and J. Baker. 1994. Do retail store environmental factors affect consumers' price acceptability? An empirical examination. Int. J. Res. Market. 11:107-115.

Herzog, T.R. 1989. A cognitive analysis of preference for urban nature. J. Environ. Psychol. 9:27-43.

Herzog, T., and T.A. Gale. 1996. Preference for urban buildings as a function of age and nature context. Environ. Behav. 28(1):44-72.

Herzog, T.R., and R.L. Shier. 2000. Complexity, age, and building preference. . Environ. Behav. 32(4):557-575.

Hudspeth, T.R. 1986. Visual preference as a tool for facilitating citizen participation in urban waterfront revitalization. J. Environ. Manage. 23:373-385.

Hull, R.B. 1992. How the public values urban forests. J. Arboric. 18(2):98-101.

Jacoby, J., and J. C. Olson. 1987. Perceived Quality: How Consumers View Stores and Merchandise. Lexington Books, Lexington, MA.

Jones, K., and J. Simmons. 1995. The Retail Environment. Routledge, New York, NY.

Kaplan, R. 1985. The analysis of perception via preference: A strategy for studying how the environment is experienced. Landscape Urban Plann. 12:161-176.

Kaplan, R., and S. Kaplan. 1989. The Experience of Nature: A Psychological Perspective. Cambridge University Press, Cambridge, UK.

Kuo, F.E. The role of arboriculture in a healthy social ecology. J. Arboric. 29(3):148-155.

Lindquist, J.D. 1975. Meaning of image: A survey of empirical and hypothetical evidence. J. Retail. 50(4):29-38.

Martineau, P. 1958. The personality of the retail store. Harvard Bus. Rev. 36:47-55.
McDonald, W.J. 1994. Psychological associations with shopping: A moderator variable perspective. Psychol. Market. 11(6):549-569.

Nasar, J.L. 1987. Environmental correlates of evaluative appraisals of central business scenes. Landscape Urban Plann. 14:117-130.

Robson, C. 2002. Real World Research: A Resource for Social Scientists and Practitioner-Researchers. Blackwell, Oxford, UK.

Schroeder, H.W., and S.R. Ruffolo. 1996. Householder evaluations of street trees in a Chicago suburb. J. Arboric. 22(1):35-43.

Sheets, V.L., and C.D. Manzer. 1991. Affect, cognition, and urban vegetation: Some effects of adding trees along city streets. Environ. Behav. 23(3):285-304.

Smardon, R.C. 1988. Perception and aesthetics of the urban environment: Review of the role of vegetation. Landscape Urban Plann. 15:85-106.

Smith, K. 2001. Director of National Main Street program, Washington, DC. E-mail personal correspondence (October).

Sommer, R. 1991. Public perceptions of street trees. In Rodbell, P.D. (Ed.). Alliances for Community Trees: Proceedings of the Fifth Urban Forestry Conference. The American Forestry Association, Washington, DC.

Ulrich, R.S. 1986. Human responses to vegetation and landscapes. Landscape Urban Plann. 13:29-44.

Veryzer, R.W. 1999. A nonconscious processing explanation of consumer response to product design. Psychol. Market. 16(6):497-522.

Weiner, B. 2000. Attributional thoughts about consumer behavior. J. Consumer Res. 27(3):382-387.

Wolf, K.L. 2003a. Public response to the urban forest in inner-city business districts. J. Arboric. 29(3):117-126. . 2003b. Retail and urban nature: Creating a consumer habitat. Populat. Environ. Psychol. Bull. 29(1):1-6.

2004. Nature in the retail environment: Comparing consumer and business response to urban forest conditions. Landscape J. 23(1):40-51. 
Acknowledgments. Many people helped make this study possible. Appreciation is extended to Roger Cauthen and Connie Head of Unified Government of Athens-Clarke County, Georgia; Art Jackson of Athens Downtown Development Authority; and Ingrid Sather of the USFS Southern Center for Urban Forestry Research and Information. University of Georgia students conducted the on-site surveys: Melinda Copeland, David James, Richard Jones, Ginny Lipscomb, Kevin Middlebrooks, Amanda Newman, Jennie Lynn Rudder, and Rashida Stanley.

This research was funded in part by a USDA Forest Service Urban and Community Forestry Financial Assistance Grant, administered by the Georgia Forestry Commission. Correspon- dence concerning this article should be addressed to the author at kwolf@u.washington.edu. Additional information can be found www.cfr.washington.edu/research.envmind.

Research Assistant Professor

Urban Forest Environment and Behavior

College of Forest Resources

University of Washington

Box 352100

Seattle WA 98195-2100, U.S.

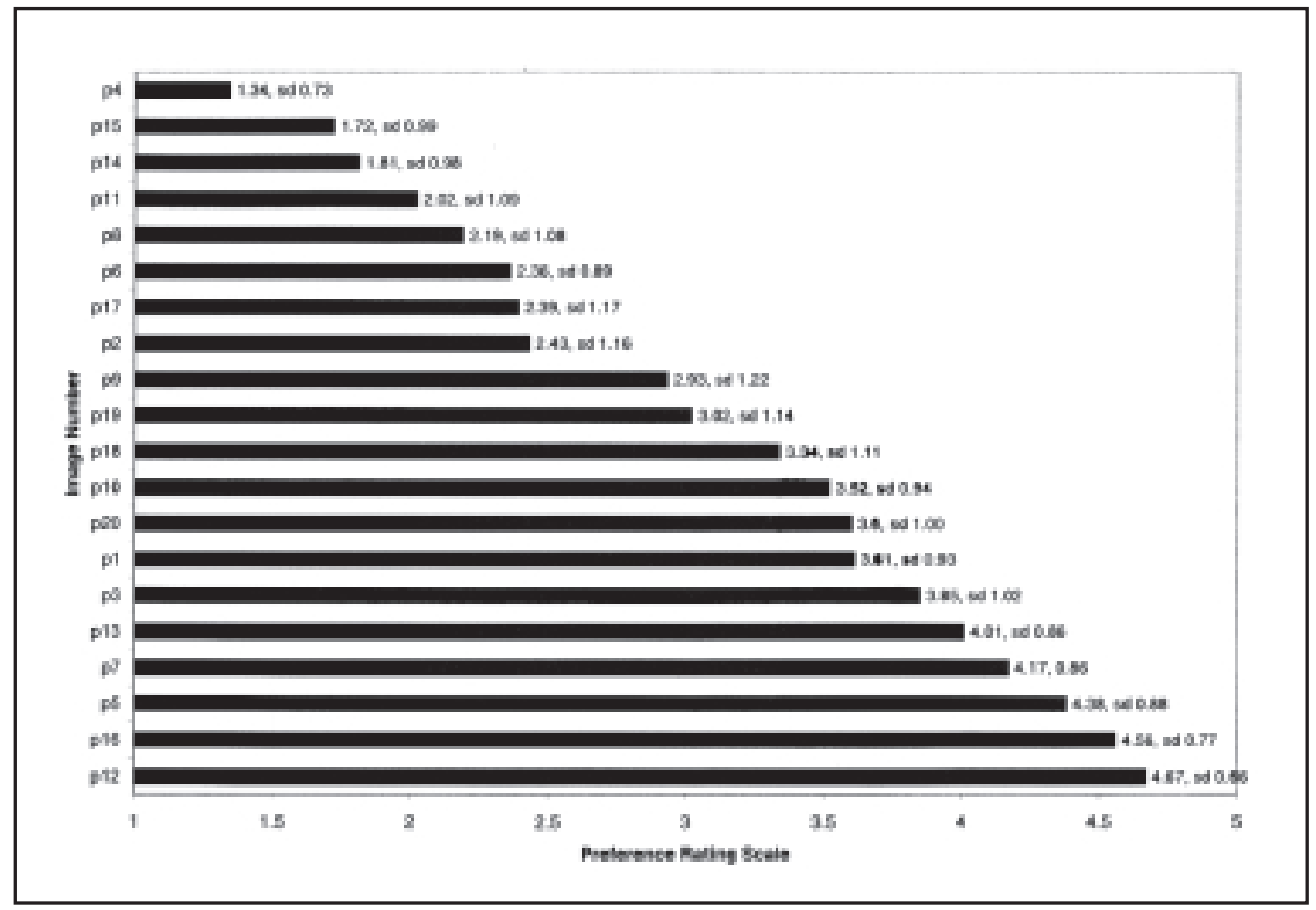

Figure 1. Preference ratings. 


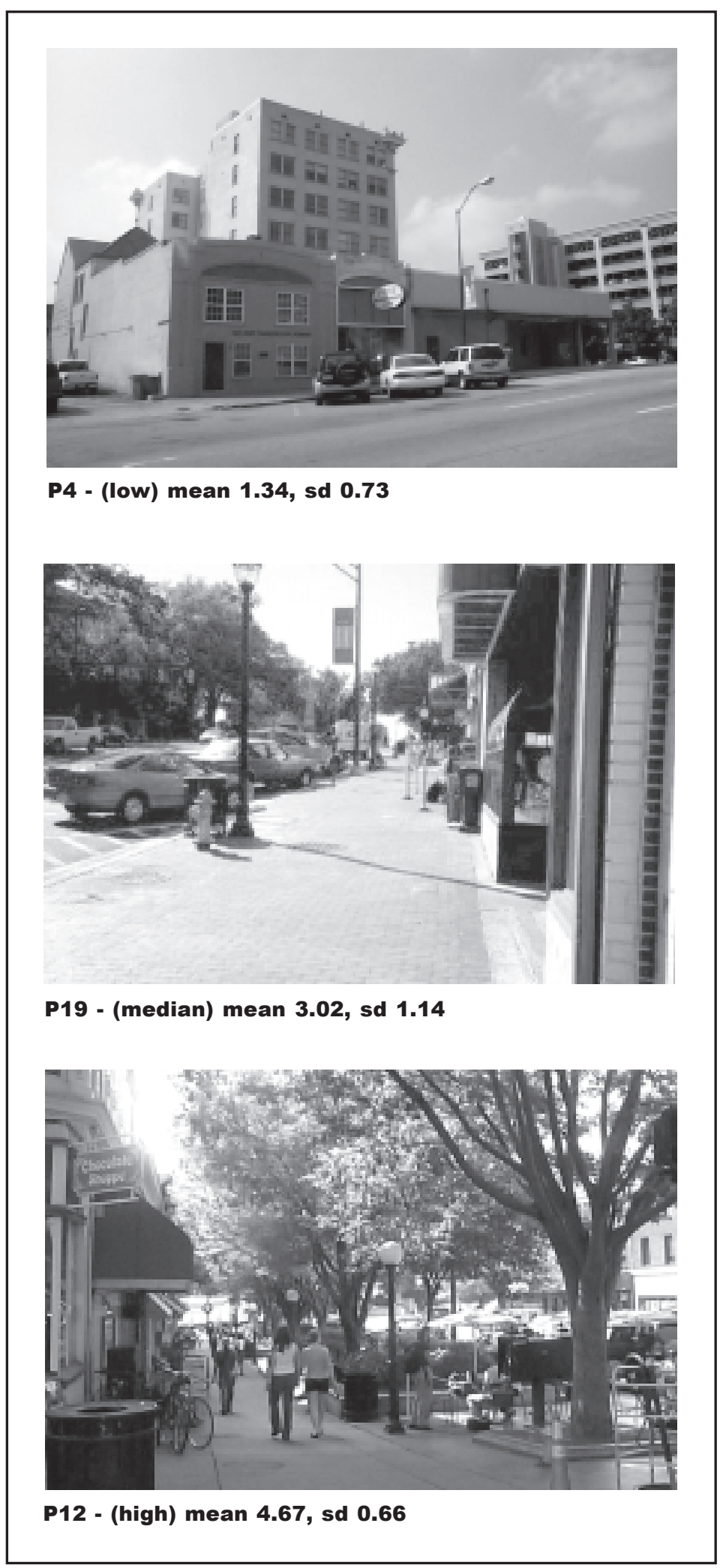

Figure 2. Range of preference ratings. 


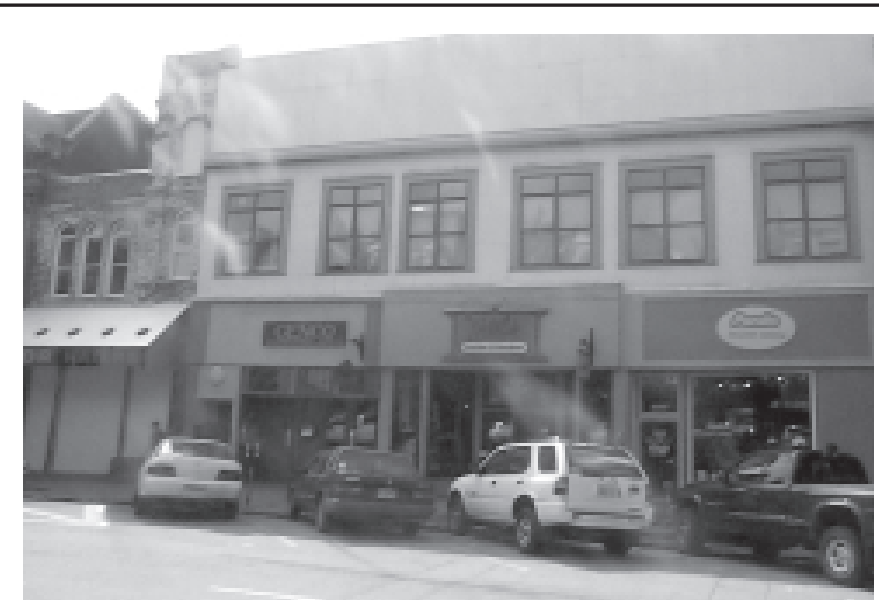

load .773 - mean 2.19, sd 1.08

Category 1: Dominant Buildings, mean 1.98, sd 0.71

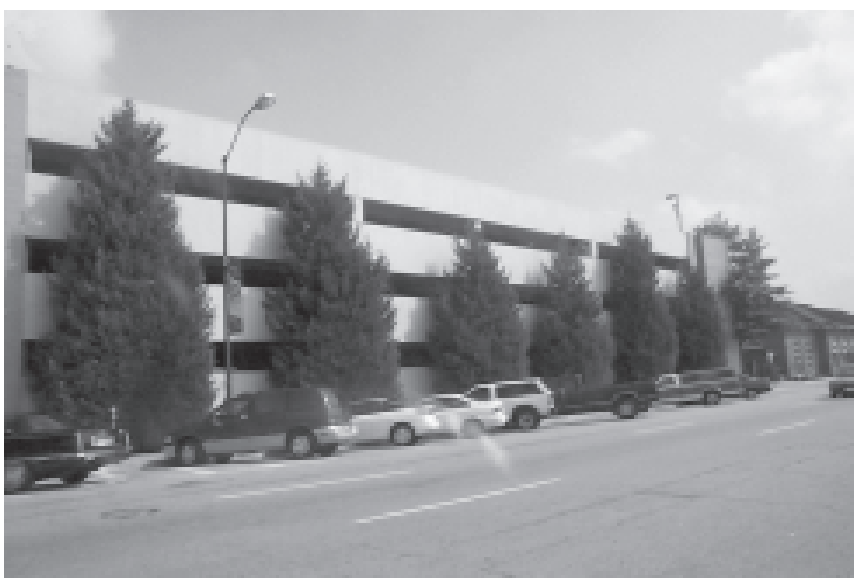

load .628 - mean 2.93, sd 1.22

Category 2: Buffered Buildings, mean 3.13, sd 1.00

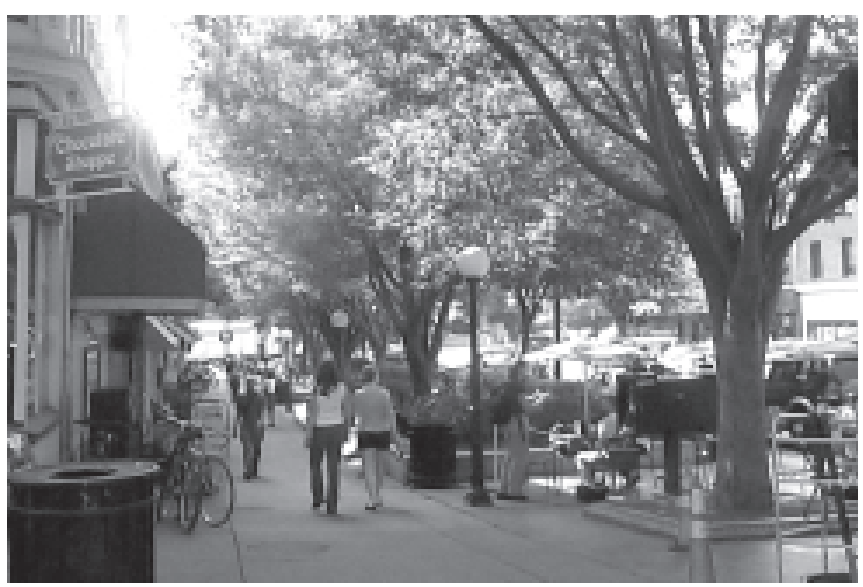

load .761 - mean 4.67 (high), sd 0.66

Category 3: Green Streets, mean 4.00, sd 0.60

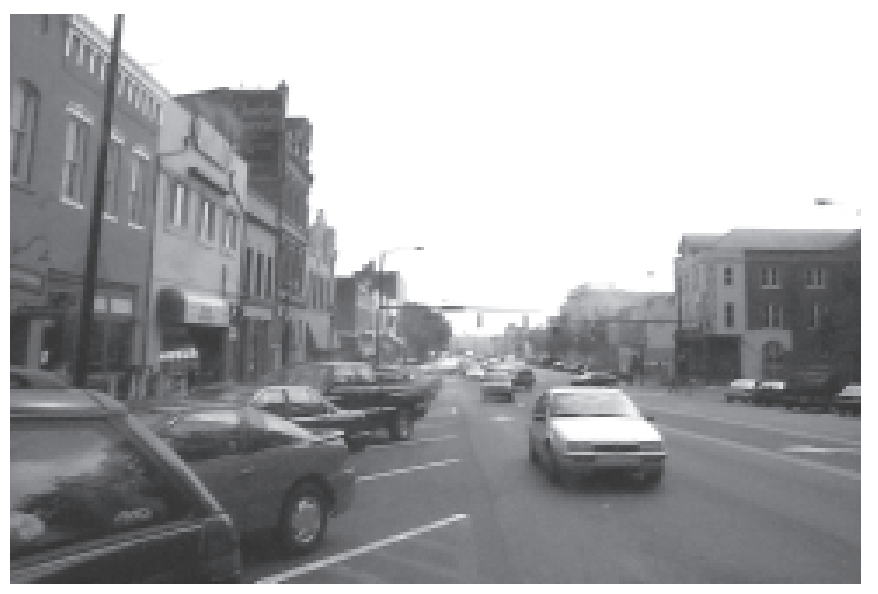

load .736 - mean 1.81, sd 0.98

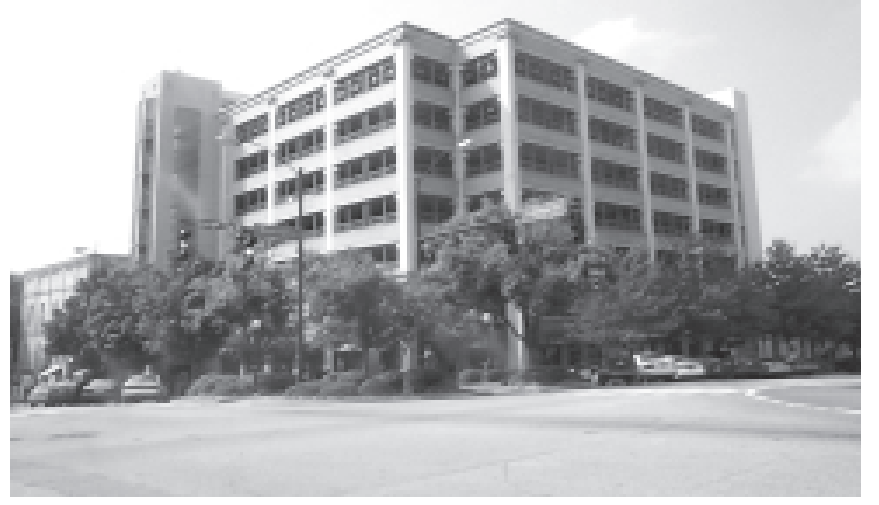

load .604 - mean 3.34, sd 1.11

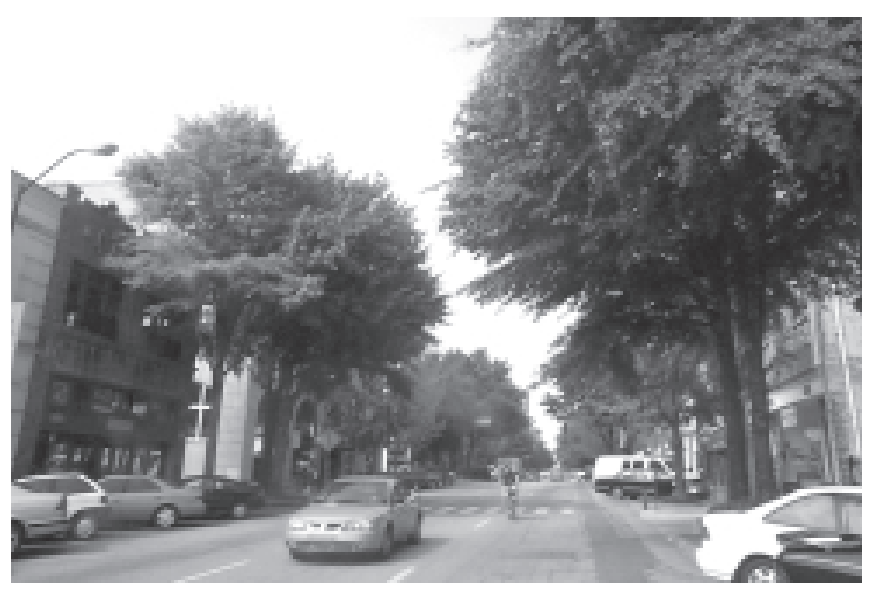

load .702 - mean 4.17, sd 0.86

Figure 3. Image categories. 
Zusammenfassung. Als Teilnehmer an einem Hauptstraßenprogramm hat Athens, Georgia, U.S., auch Baumpflanzungen als Straßenbegleitgrün in wirtschaftlichen Entwicklungsanstrengungen beigefügt. Das nationale Hauptstraßenprogramm hilft Händlergruppen im Stadtzentrum durch physische Fortschrittsplannung, um nachhaltige Entwicklungen zu kreieren. Wenn es ausführlich geleitet wird, kann der städtische Wald eine nützliche Verbesserung sein. Nichtsdestoweniger haben Geschäftsleute und Kaufleute oft negative Wahrnehmungen ihrer Bäume, wie Z.B. reduzierte Verkehrszeichensicht-barkeit und Rückstände in Form von Laub und Ästen und Beeinflussen möglicherweise die Lokalpolitik und finanzielle Unterstützung für städtische Forstprogramme. Die Präsenz eines geschlossenkronigen Waldes wurde verbunden mit den höheren visuellen Qualitätsklassen in dem Entwicklungsbezirk. Die Besucher dieses Distrikts empfinden das Laubdach auf den Strassen als integrales Gestaltungselement in dem innerstädtischen Einkaufsambiente. Quantitive und qualitative Forschungsergebnisse werden berichtet.

Resumen. Como participante en el programa Main Street, Athens, Georgia, U.S., ha incluido las plantaciones de árboles en sus esfuerzos económicos de desarrollo. El Programa Nacional Main Street asiste a los grupos ciudadanos con mejoramientos de planeación física con el fin de crear mejores ambientes. Si es bien manejado, el bosque urbano puede ser un beneficio a largo plazo. Por otra parte, la gente de negocios y los comerciantes con frecuencia tienen percepciones negativas acerca de los árboles (tales como reducción de la visibilidad de sus anuncios y basura) y pueden influir sobre las políticas locales y presupuestos para los programas forestales urbanos. Este estudio utilizó una encuesta para determinar las preferencias y respuestas en percepción para los visitantes del distrito central de negocios de Athens, GA. La presencia de una cobertura total fue encontrada asociada con los más altos registros de calidad visual en el distrito. Los visitantes también percibieron que la cobertura arbórea contribuye a crear un ambiente integral para las compras en la ciudad. Se reportan resultados cuantitativos y cualitativos de la investigación.

Résumé. Dans son programme participatif pour sa rue principale, la ville de Athens en Georgie a inclus des plantation d'arbres dans els efforts de développement économique. Le Programme national de la rue principale assiste les groupes de commerçants de centre-ville au niveau de la planification d'améliorations physiques dans el but de créer des environnements vitaux de magasinage. Si cela est géré de manière soignée, la forêt urbaine peut s'avérer être une amélioration à long terme bénéfique. Quoiqu'il en soit, les gens d'affaires et les commerçants ont souvent des perceptions négatives à propos des arbres - comme visibilité réduite des enseignes, débris - et peuvent influencer la politique locale et le support budgétaire pour les programmes de foresterie urbaine. Cette étude fait appel à un inventaire sur le site pour mettre à jour les préférences et les réponses des visiteurs du secteur commercial central de Athens. On a découvert que la présence d'un couvert arboré complet a été associé à une qualité visuelle ples élevée du secteur commercial. Les visiteurs de cette zone ont aussi perçu le couvert arboré de la rue comme étant une composante essentielle de son environnement de magasinage. Des recherches qualitatives et quantitatives sur les conséquences sont aussi fournies. 